\title{
The Principle of Transparency and Access to Documents in the EU: for what, for whom, and of what?
}

\author{
Joana Mendes*
}

Abstract: Written as a chapter for the third edition of the Traité de Droit Administratif Européen, directed by Jacqueline Dutheil de la Rochère and Jean Bernard Auby (Bryulant, forthcoming), this paper characterizes transparency as an ambivalent principle of EU law and governance, serving both a functional and a democratic rationale. The analysis focuses on the right of access to documents, a right whose scope and democratic function very much depend on who requests and on the interpretation of the exceptions to access. While the former is a matter of practice, the latter is essentially the result of the main approaches that the Court of Justice of the European Union (CJEU) has followed hitherto: strict interpretation and application of the exceptions, on the one hand, and general presumptions of non-disclosure, on the other. The paper presents both. It argues that, while much criticized in the literature as contrary to the democratic function of the regulation on access to documents, general presumptions of non-disclosure merit a more nuanced analysis. They can be, under restricted circumstances, a way to protect the democratic function of the citizen's right to access. Yet, the uncertain and evolving criteria for the establishment of a general presumption of non-disclosure have effectively carved out whole categories of documents from the possibility of access, insulating significant sections of EU public action from the pressure of democratic claims. Overall, the right of access to documents, as ancillary to a principle of democracy, has a limited capacity to change the nature of the polity and of the system of governance in which it is embedded.

\section{Introduction}

A person interested in, but unfamiliar with, the European Union, trying to understand its functioning, its ethos, its policies, the intricacies of its decision-making process, is confronted with a wealth of information and with multiple sources where more documents can be found. Public reports, guidance documents, programmes and strategies, are routinely made public informing experts in EU affairs and the general public, in constant flows of information that overwhelm.

\footnotetext{
* Professor of Comparative Administrative Law, University of Luxembourg. Thanks are due to Leonor Rossi for useful comments and to Martin Petschko, for excellent research assistance. The chapter refers to the law as it stood in January, $30^{\text {th }} 2020$, without aiming at a comprehensive coverage of the case law on access to documents.
} 
Registers and databases of the EU institutions, in addition to information made available on request, allow one to access working documents, agendas, minutes and voting details of various meetings, webstream public sessions (for example, of the Council of Ministers) ${ }^{1}$ and, eventually, to reconstruct decision-making procedures. If transparency stands for availability of information, by all means the EU is a transparent polity. If, in a mode demanding reading, transparency stands for the availability of norms and mechanisms that rule conflicts of interests, frame lobbying activities, and induce ethical rules of behavior on the part of decision-makers, also on this frontthe remaining shortcomings notwithstanding - one may point to the rules of procedure and codes of conduct of the institutions, but also to the stalled negotiations on a mandatory lobbying register. ${ }^{2}$ Prima facie, one could argue that transparency is an everyday reality, anchored in the norms and practices that have evolved over the years of EU integration. But this statement, of course, only tells part of the story. Shortcomings both in norms and practices are reflected in court litigation and in Ombudsman's inquiries. ${ }^{3}$ More recent initiatives of the EU institutions, too, indicate the continuous need to address perennial problems, such as the transparency of the expertise provided by scientific committees and conflicts of interests that may fraught decisionmaking. ${ }^{4}$

The principle of transparency in the law of the EU continues in need of being carefully woven through adequate legal norms and suitable institutional practices, positing normative change. In its current constitutional framework, the direction of such change is unequivocal: transparency is ancillary to democracy and EU law should be shaped progressively to enable it.

\footnotetext{
1 https://video.consilium.europa.eu/en/webcasts

2 European Parliament Decision on the general revision of Parliament's Rules of Procedure (2016/2114(REG), 13.12.2016, and European Parliament Decision on amendments to Parliament's Rules of Procedure affecting Chapters 1 and 4 of Title I; Chapter 3 of Title V; Chapters 4 and 5 of Title VII; Chapter 1 of Title VIII; Title XII; Title XIV and Annex II (2018/2170(REG), 31.01.2019, tightening the rules on the transparency register and making amendments directed at ensuring transparency throughout decision-making processes; Commission Decision C/2018/0700, of 31 January 2018, on a Code of Conduct for the Members of the European Commission OJ C 65, 21.2.2018, p. 7-20; Proposal for an Interinstitutional Agreement on a Mandatory Transparency Register, COM(2016) 627 final, Brussels, 28.9.2016.

${ }^{3}$ See, further, Sections 3 and 4 below. This chapter will focus on the case law analysis. For an overview of the work of the European Ombudsman in the area of transparency, see, e.g. N. VogIaTZIS, The European Ombudsman and Good Administration in the European Union, Palgrave, 2018, Chapter 5; H. MiCHEL, «Le Médiateur Européen Héraut de la Transparence. Redéfinition d'une Institution et Investissements Politiques d'une Norme de «Bon » Gouvernement », Politique Européenne, 2018/3, Vol. 61, 2018, pp. 114 -141; D. Dragos AND B. NEAMTU, « Freedom of Information in the EU in the Midst of Legal Rules, Jurisprudence and Ombudsprudence: the European Ombudsman as Developer of Norms of Good Administration », European Constitutional Law Review, Vol.13(4), 2017, pp. 641-672.

${ }^{4}$ Regulation (EU) 2019/1381 of the European Parliament and of the Council of 20 June 2019 on the transparency and sustainability of the EU risk assessment in the food chain (OJ L 231, 6.9.2019, p. 1-28), in particular recitals 34 and 37. See also European Parliament Report on transparency, accountability and integrity in the EU institutions (2015/2041(INI)), 30.03.2017.
} 
However, this reading ignores the instrumental role of transparency in supporting the effectiveness of EU integration and in institutionalizing governing practices anchored in the relationship between the EU and interest representatives. The first question one should bear in mind when assessing transparency in the EU is "for what?", since the purposes of transparency are far from univocal (Section 2). Against this background of ambivalence, this chapter will analyze the right of access to documents to show the legal and practical difficulties in giving effect to a political right of democratic imprint in the context of EU integration. These stem from the actual practice of requesting documents, since requests are frequently filed by natural and legal persons who seek to reap commercial advantages from disclosure. EU law, as a matter of principle, does not allow a differentiated treatment of access in this regard. Yet, "for whom" transparency works remains a relevant question to assess the ability of the right of access to documents to fulfil its democratic rationale (Section 3). The difficulties of realizing this function stem as well from the specific functioning of the exceptions that EU law currently envisages. Notwithstanding the principled nature of transparency, and the democratic inspiration of the current regulation on access to documents, the effective scope on access to documents decisively depends on what is being requested and how the competing interests of access and confidentiality play out in each instance. Transparency "of what?" will therefore occupy most of the chapter, analyzing the judicial interpretation of the exceptions (Section 3) and, through selected examples, how the case law has defined concrete borderlines between democracy and confidentiality (Section 4).

\section{Transparency in EU integration: an ambivalent principle}

Transparency has been a normative concern in EU integration at important points of its history. While the Treaty of Maastricht and the political union are usually considered the original hallmarks of the transparency turn in the EU, the importance given to the visibility of the actions of the institutions as a condition for its success was already present in the setting up of the European Coal and Steel Community in the mid-1950s. Transparency was an important part of making sure that both Member States and undertakings subject to the power exercised by the Community institutions, in particular the independent High Authority, would understand and accept it. This was essential to the ability of the new Community to affirm itself as a legitimate authority. ${ }^{5}$ In the

\footnotetext{
5 P.Reuter, La Communauté Européenne du Charbon et de l'Acier, Paris, LGDJ, 1953, p. 76, refering that the common market should be a "glass house ». On the ways in which, within the state setting, transparency has become the foundation of public action, rather than a means of public action, see J.F. KERLÉO, «Comprendre l’État sous le Regard de la Transparence », Droit et Societé, 2019/2, 2019, pp. 379-396, at pp. 382-385 (« la transparence est devenue un horizon à atteindre pour tout pouvoir qui cherche à asseoir son autorité sur un fondement légitime », at p. 385)
} 
decades that followed, however, when at all a consideration, transparency fulfilled less foundational functions. It remained instrumental to the building of the internal market.

In the 1980s, when the Commission launched its initiative on completion of the internal market, lack of transparency was perceived to be a problem for the effective application of Community law: the removal of trade barriers required that both Member States be aware of their obligations and the "Community citizens" in the know regarding their rights. ${ }^{6}$ Transparency stood here for communication, presupposing access to information but requiring a specific reach-out strategy that the Commission avowed to undertake. It took, however, a somewhat strengthened form in the 1992 Sutherland Report, which laid the seeds for what later became the Impact Assessment Procedure. There, in addition to communication ("targeted as closely as possible on particular sections of the public concerned"), transparency appeared as a quality of the Community rule-making procedures and came hand in hand with the participation "of those concerned by [law]", namely of consumers and firms. ${ }^{7}$ The risk seen in interrupting a continuous "dialogue with European organisations" was the same that had brought transparency to the forefront of structural principles in the ECSC Treaty: "the risk of [Community rules] being perceived as technocratic constraints, even as interference [...], rather than as contributions to the wider ideal of the internal market". 8 Transparency, therefore, came in the guise of openness, presupposing an active stance to involve those concerned by legal acts. ${ }^{9}$ But transparency of Community law meant also legislative consolidation, a legislative technique at the service of the rule of law requirement of clarity, without which the effectiveness of the internal market legislation could be imperiled. ${ }^{10}$

By the time when transparency emerged as one of the cornerstones of the Commission's strategy to ensure the realization of the "ideal of the internal market", as set out in the Sutherland

\footnotetext{
${ }^{6}$ White Paper from the Commission to the European Council, Completing the Internal Market, COM (85) 310 final, 14 June 1985 (Milan, 28-29 June 1985), para 155.

${ }^{7}$ Report to the EEC Commission by the High Level Group on the Operation of the Internal Market, presided over by P. Sutherland, «The Internal Market After 1992. Meeting the Challenge », (SEC(92) 2044, 28 October 1992, European Report n. 1808, p. 5-6 (and Recommendations 8 and 9).

${ }^{8}$ Ibidem, p. 6.

9 On the ambiguous relationship between transparency and openness, albeit in the post-Lisbon contest, see A. ALEMANNO, «Unpacking the principle of openness in EU law: transparency, participation and democracy », European Law Review, 2014, 39(1), 72-90, stressing that openness presupposes "the adoption of a multitude of behaviours on the part of the institutions to promote other superior goals" (p. 74).

10 Under the heading "Transparency of Community Law", the Reports' recommendation regarding legislative consolidation is compounded with the need to act at the level of transposition of directives - which "pose obvious limits to transparency" - and a clear preference for the use of regulations (idem, Recommendations 10, 11 and 13, p. 7-9).
} 
Report, ${ }^{11}$ the institutional discourse on transparency in the EC/EU had started taking a different turn. In 1992, the famous Declaration No. 17 had already been annexed to the Maastricht Treaty, holding that transparency "strengthens the democratic nature of the institutions and the public's confidence in the administration". When the European Council met late that year (first in Birmingham, in the wake of the Danish referendum's rejection of the Maastricht Treaty, and then in Edinburg), it discussed both the recommendations of the Sutherland Report on transparency and ways of making the "Community close to its citizens". ${ }^{2}$ Soon thereafter transparency found a firm legal ground in the Treaty, following the Amsterdam revision in 1999. Access to documents of the European Parliament, the Council and the Commission became a right of citizens and of natural or legal persons residing or having their registered office in a Member State - a fundamental right, after the adoption of the Charter of Fundamental Rights in $2000 .{ }^{13}$ Furthermore, a legal basis allowed for the adoption of an act defining the conditions of access to documents - Regulation 1049/2001, still in force today - and the European Parliament, the Council and the Commission had henceforth the duty to adopt rules of procedure on access to their documents. ${ }^{14}$ These leads were taken up both by litigants before the Court of Justice and by the European Ombudsman, which soon became known for its advocacy of access to documents and transparency. From these starting points, transparency soon became a hallmark of democracy in the EU, not only in political discourse but also as a matter of EU law. ${ }^{15}$

Transparency serving "the ideal of the internal market" and transparency as a feature of a democratic polity in the making remain present and intertwined ever since in both EU law and institutional practice. "Actively [communicating] about what the EU does" in language that is "accessible and understandable for the general public" (transparency as communication) became a principle of good governance, under the heading of "openness", proclaimed in the White Paper

11 On how the Commission endorsed the Sutherland Report, see Communication from the Commission to the Council and the European Parliament - The Operation of the Community's Internal Market After 1992 Follow-Up to the Sutherland Report (Sec/92/2277final), in particular points 44-48.

12 See Birmingham Declaration (annex I to the Presidency Conclusions of the European Council, Birmingham, 16 October 1992), and Presidency Conclusions of the European Council Edinburg, 11-12 December 1992, points 4 and 16. On these and on the broader context of this period, see, inter alia, H. MiCHÈLE, «La Transparence dans L'Union Européenne Réalisation de la Bonne Gouvernance et Redéfinition de la Démocratie », Revue Française d'Administration Publique, Vol. 2018/1, 2018, pp. 109-126, at p. 112-116.

13 Article 42 of the Charter of Fundamental Rights.

14 Article 191A of the Treaty of Amsterdam. Regulation No. 1049/2001 of the European Parliament and of the Council of 30 May 2001 regarding public access to European Parliament, Council and Commission documents, OJ L 145/43.

15 Regulation 1049/2001, recital 2. Joined Cases C-39/05 P and C-52/05 P, Sweden and Turco v Council EU:C:2008:374, 2005, para 46. 
on Governance of $2001 .{ }^{16}$ It went hand in hand with the involvement of "civil society in policymaking. Combined, transparency and participation were meant to create more confidence in the EU institutions and in their policy. Despite the language loosely resonant of democratic ideals ("civil society", "giving voice", "inclusive" and "accountable" policy-making), it is the effectiveness of the integration process that underlines the principles of good governance. ${ }^{17}$ With this ethos, transparency (as well as participation) remains to this day a fundamental part of the Commission's Better Regulation policy, a cornerstone of "improving the quality of legislative proposals". ${ }^{18}$ In this role, it further justified a series of initiatives, ranging from minimum standards of consultation to lobbying regulation, that have changed both how the EU makes law and policy and how it relates to interest representatives. ${ }^{19}$ They institutionalized a way of governing via consultation of interest groups, by now broadly accepted in the name of fully informed decisionmaking, based on the available knowledge and on an assessment of the variety of views expressed (in short, better policy-making), and of the effectiveness of the decisions adopted (which the involvement of those affected facilitates). ${ }^{20}$ While this change was taking form, the Draft Treaty establishing the Constitution for Europe prepared the ground for the distinctive constitutional language later introduced by the Lisbon Treaty. As a matter of Treaty determination, openness is now at the core of the democratic foundations of the Union, being ancillary to representative democracy and to participatory democracy (Articles 10(3) and 11(2) TEU), as well as to good governance (Article 15(1) TFEU). The legislature's duty to act publicly (Article 15(2) TFEU) is an

${ }^{16}$ Communication from the Commission, "European Governance - A White Paper", COM(2001) 428 final, Brussels, 25.7.2001, p. 10 and p. 11 (under "Making the way the EU works more open...").

${ }^{17}$ Ibidem, p. 7.

18 Communication from the Commission, "Action plan 'Simplifying and improving the regulatory environment' (COM/2002/0278 final), point 1.1. See too Communication from the Commission to the European Parliament, the Council, the European Economic and Social Committee and the Committee of the Regions, "Better regulation for better results - An EU agenda", COM(2015) 215 final, Strasbourg, 19.5.2015; and Staff working document, "Better Regulation: taking stock and sustaining our commitment" $\operatorname{COM}(2019) 178$ (available at https:/ / ec.europa.eu/info/publications/better-regulation-taking-stock-and-sustaining-our-commitment en);

Interinstitutional Agreement Between the European Parliament, the Council of the European Union and the European Commission on Better Law-Making (OJ L 123/1, 2.5.2016).

19 Communication from the Commission, "Towards a reinforced culture of consultation and dialogue - General principles and minimum standards for consultation of interested parties by the Commission", COM(2002) 704 final, Brussels, 11.12.2002, subsequently adapted by a series of communications (see "Better regulation for better results An EU agenda”, $\operatorname{COM(2015)~} 215$ final, cit., point 2.1.); and Commission, Green Paper - European transparency initiative (COM(2006)0194 final, Brussels, 3.5.2006), including proposals on anti-fraud and financial management and on ethical behavior of EU officials. See, more recently, Proposal for an Interinstitutional Agreement on a mandatory Transparency Register COM(2016) 627 final, Brussels, 28.9.2016.

20 See, further, C. RoberT, «La Politique Européenne de Transparence (2005-2016) : de la Contestation à la Consécration du Lobbying », Gouvernment et Action Publique, No 1, 2017, pp. 9-32, for a sociological analysis of this transformation. 
epitome of the constitutional transformation that the Lisbon Treaty meant to introduce, as is, arguably, the requirement of an open European administration (Article 298(1) TFEU).

This brief overview is enough to show what is perhaps one of the core characteristics of transparency: its ambivalence. The reasons why, at different moments in the process of EU integration, transparency was either an important concern or at the forefront of policy-making are varied. Both the vagueness of the concept and the institutional and academic discourses built around the role of transparency in the EU make it at times difficult to isolate those reasons, blurred in the "overall consensus" surrounding the values of transparency. ${ }^{21}$ Transparency, in the EU and elsewhere, has become "an end in itself" with little questioning about its potential contested sides, ${ }^{22}$ except to the extent that the ways of practicing transparency can be criticised, because they fall short of transparency's normative promises. ${ }^{23}$ Yet, in particular in the EU context, one ought not lose sight of "what are we calling for when we call for transparency". ${ }^{24}$ Here, the ambivalence of transparency is marked by the tension between the functional and the democratic claims that it serves. Arguably, in the EU and elsewhere, transparency has been instrumental to a debased conception of democracy, where the citizen, often lacking the resources to take up an active role of monitoring and participating, is often replaced by interest representatives, by non-governmental organisations, and by members of the European Parliament. ${ }^{25}$ Even without the intimate association to participation that transparency has acquired in EU governance, the availability of information in itself changes the relationship between the holders of public power and society. It makes the former more permeable to external influences and can impinge on the content of the decisions taken, either by way of such influences or, more indirectly, of the adjustment by decisionmakers to the expectations of those who will have access to the decision. ${ }^{26}$ Beyond (and because of the possibilities of control over the exercise of public power, which it facilitates, transparency generates asymmetries between public and private actors that need to be acknowledged when

\footnotetext{
${ }^{21}$ E. AlloA, «Transparency: A Magic Concept of Modernity », in E. AlloA And D. Thomä (eds), Transparency, Society and Subjectivity: Critical Perspectives (Palgrave), pp. 21-55, 2018, at pp. 28-29, further stating that "in a society rule by the paradigm of transparency, transparency itself represents a blind spot” (at p. 46).

22 D. E. Pozen, «Transparency's Ideological Drift », Yale Law Journal, Vol. 128, pp. 100-165, 2018, at p. 103 ; I. Koivisto, « The Anatomy of Transparency: The Concept and its Multifarious Implication » EUI Working Papers MWP 2016/09, 2016.

${ }^{23}$ For an overview of the literature on the EU, see C. ROBERT, op. cit., p. 11-12.

24 I. KOIVISTO, op. cit., p. 2.

${ }^{25}$ C. RoberT, op. cit., p. 34-35. H. Michel, « La Transparence dans L’Union Européenne : Réalisation de la Bonne Gouvernance et Redéfinition de la Démocratie », Revue Française d'Administration Publique, Vol 2018/1, 2018, pp. 109126.

26 J.F. KERLEO, op. cit., p. 390, 392-3, arguing, in addition, that transparency may be "une cause explicative et déterminante des évolutions de la puissance publique » (p. 393).
} 
pleading in its favour. At the same time, transparency as ancillary to an ideal of democracy has also contributed to give EU decision-making processes characteristics that resemble those of representative democracies (e.g. the constitutional determination that the legislature needs to act publicly).

The right of access to documents - transparency's legal form par excellence - does not escape the tension between the functional (an instrument to "promoting the ideal of the internal market") and democratic rationales of transparency, as the reminder of the chapter will show. After a general mapping of the right's legal framework, which endorses its democratic function (Section 3.1), a more detailed analysis of those who benefit from access to documents (Section 3.2) and of the interpretation of the exceptions that can prevent disclosure (Section 3.3) will reveal how practice qualifies and delimits the rights' democratic function.

\section{Access to Documents and the Tensions of EU Integration}

\subsection{Institutions, documents and rationale: some preliminary observations}

The right of access to documents is enshrined in Article 42 of the Charter of Fundamental Rights and in Article 15(3) of the Treaty on the Functioning of the European Union (TFEU). It is exercised in the terms of Regulation 1049/2001, which, in line with the original Article 191A of the Treaty of Amsterdam, applies only to requests made to the European Parliament, Council and Commission. ${ }^{27}$ Requests on access to documents made to other institutions, bodies, offices and agencies fall within the scope of the regulation, mostly as a result of voluntary adherence through internal rules of procedures or by way of specific legal provisions (in particular in the case of agencies). ${ }^{28}$ Article 15(3) TFEU mirrors this evolution, referring broadly to "Union's institutions, bodies, offices and agencies". But, while extending the scope of the right of access to documents, it also singled out two institutions and one legal person in this: the Court of Justice of the European Union (CJEU), the European Central Bank (ECB) and the European Investment Bank (EIB) are only bound by this right "when exercising their administrative tasks". Requests of access to documents made to these entities are regulated by decisions that implement their obligation under Article 15(3) TFEU, and not by Regulation 1049/2001. ${ }^{29}$ While the rules thereby established may

\footnotetext{
27 Article 1(a) of Regulation 1049/2001; see, in this regard, Judgment of 18 July 2017, Commission v Breyer, Case C-213/15 P, EU:C:2017:563, para 37.

28 See, in more detail, L. Rossi And P. VInagre e Silva, Public Access to Documents in the EU (Hart Publishing, 2017), 2017, pp. 72-78.

${ }^{29}$ Decision 2004/258 of the European Central Bank of 4 March 2004 on public access to European Central Bank documents (OJ L 80/42, 18.03.2004); see Judgment of 19 December 2019, European Central Bank v Espírito Santo,
} 
diverge from those of Regulation 1049/2001 in significant respects - for example, as a result of the respective decisions, neither the CJEU nor the ECB are bound by an obligation to keep a register of documents - the case law developed under Regulation 1049/2001 may remain, nevertheless, relevant for the interpretation of those decisions. ${ }^{30}$

The objective scope of the Regulation depends on the notion of "documents", which is rather encompassing: documents refers to "any content whatever its medium", "drawn up or received by it and in its possession, in all areas of activity of the European Union" (hence also documents authored by other entities). ${ }^{31}$ Nevertheless, what counts as document can be a controversial matter. That is the case, in particular, of access to information contained in databases. In this respect, the Court has held that "document" refers to "content that is saved and that may be copied or consulted after it has been generated", covering potentially the entirety of the data contained in a database. ${ }^{32}$ The Court has held that the document requested needs to be an existing document, which excludes data that has been deleted or has not yet been added. ${ }^{33}$ Importantly, the technical specificities of a database (whether it allows to extract the information requested without substantial investment) can be determinant in defining what counts as an existing document, defining also the scope of application of the Regulation. ${ }^{34}$ Beyond the notion of document, also the classification of sensitive documents (subject to specific rules of access under Article 9 of

C-442/18 P, EU:C:2019:1117, deciding the case solely on the basis of Decision 2004/258 (see too, on the same case, Opinion of AG PIKMÄE delivered on 2 October 2019, C-442/18 P, EU:C:2019:811, para 59 to 66). Decision of the Court of Justice of the European Union of 11 December 2012 concerning public access to documents held by the Court of Justice of the European Union in the exercise of its administrative functions (OJ C 38/2, 9.2.2013); see, in this respect, Commission v Breyer, para 47 to 54. The rules applicable to the European Investment Bank are defined in guidelines ("The EIB Group Transparency Policy", 6 March 2015, available at https://www.eib.org/attachments/strategies/eib_group_transparency_policy_en.pdf).

30 In this sense, Judgment of 20 September 2019, Dehousse v Court, Case T-433/17, EU:T:2019:632, para 32 (and endorsing the view that the regulation and the decision of the Court pursue the same objective, see Commission v Breyer, para 53). For a different view, see Opinion of AG PIKMÄE in European Central Bank v Espirito Santo, cit.. On the lack of duty to keep a register, see para 63 and 64 and Case T-436/09, Dufour v ECB, EU:T:2011:634, para 155.

${ }^{31}$ Articles 2(3) and 3(a) of Regulation 1049/2001. If the documents held by the institutions originate from the Member States, agreement of the Member State concerned may be required prior to disclosure (Article 4(5) of Regulation 1049/2001; see, e.g., Judgment of 18 December 2007, Sweden v Commission, C-64/05 P, EU:C:2007:802; and Commission $v$ Breyer, para 43). Importantly, those documents are not subject to national law (see in this regard, Opinion of AG Bobek, Commission v Breyer, EU:C:2016:994, para 49). Access to documents of third parties, including of other institutions, is ruled by Article 4(4) of Regulation 1049/2001 (see, e.g. Judgment of 21 September 2010, Sweden and Others v API and Commission, C-514/07 P, C-528/07 P and C-532/07 P, EU:C:2010:541; and Commission v Breyer, para 38).

32 Dufour v ECB, para 88 and 102 to 118., On the relevance of practical difficulties that may arise in extracting documents from a database, see para 121 to 123 .

${ }^{33}$ Dufour $v E C B$, para 128 to $130,135,149$ and 152 (the requirement of existing document had been formulated in a different context in Judgement of 2 October 2014, Strack v Commission, C-127/13P, EU:C:2014:2250, para 38 and 46).

${ }^{34}$ Judgment of 11 January 2017, Typke v Commission, C-491/15 P, EU:C:2017:5, para 35 to 40. 
Regulation 1049/2001), ${ }^{35}$ and the limits of access to documents resulting from the exceptions established in Article 4 (analysed in more detail below) govern the actual access to documents requested.

The recitals of the regulation express well the democratic rationale that underpinned its adoption. Openness, as stated in the Treaty at the time of its adoption, "[marked] a new stage in the process of creating an ever closer union among the peoples of Europe, in which decisions are taken as openly as possible and as closely as possible to the citizen". ${ }^{36}$ Furthermore, it contributed to strengthening democracy and respect for fundamental rights, as well as to the legitimacy of the administration. ${ }^{37}$ Based on these premises, the regulation was adopted to give the "widest possible access to documents", and privileged access when the institutions act in a legislative capacity. ${ }^{38}$ To this day, the judgment in Turco remains emblematic of the Court's most progressive stance regarding the fulfilment of the democratic function of the right of access to documents that the regulation announces. Countering the Council's claim that disclosure of an opinion of its legal service pertaining to a legislative proposal could lead to doubts as to the lawfulness of the legislative act, the Court upheld "the democratic right of European citizens to scrutinize the information which has formed the basis of a legislative act", holding that openness "contributes to conferring greater legitimacy on the institutions in the eyes of European citizens and increasing their confidence in them by allowing divergences between various points of view to be openly debated." ${ }^{39}$

Nevertheless, as will be seen in more detail below, the law and practice of access to documents of the EU institutions, bodies, offices and agencies, restricts in important respects the democratic function of this right. In some cases, the Courts have sought to preserve this function, by shielding the exercise of the right from usages that could subvert its democratic rationale. In other cases, the case law has arguably contributed to limiting the scope of access to documents in ways that reflect the functionalist context in which this right is exercised and that, in addition, further the functional ethos of the EU polity. This tension will be further analysed by examining

\footnotetext{
35 See, e.g., D. CuRTIN, « Judging EU Secrecy » Cahiers de Droit Européen, Vol. 2, 2012, pp. 457-490; D. CuRTIN, « Official secrets and the negotiation of international agreements: Is the EU executive unbound? » Common Market Law Review, Vol. 50, No. 2, 2013, pp. 423-457.

36 Text of what was then Article 1 of the Treaty on the European Union, reproduced in recital 1 of Regulation $1049 / 2001$.

${ }^{37}$ Recital 2 of Regulation 1049/2001.

38 Article 1(a) of Regulation 1049/2001 and Recitals 4 and 6 of Regulation 1049/2001.

39 Sweden and Turco $v$ Council, para 67 and 59. This same point was reiterated in subsequent judgments with equally important consequences (e.g. Case T-540/15, De Capitani v Parliament, EU:T:2018:167, para 78).
} 
the extent of transparency, but it is equally present regarding the beneficiaries of the right of access to documents.

\subsection{Holders of the right and its active users}

The degree and the object of transparency that the regulation on access to documents allows for depends firstly on who can have access. Requests are where access starts. In this respect, the regulation is clear, and equally in line with the democratic function of the right: citizens, residents, but also legal persons with registered office in a Member State, can have access without needing to provide reasons. ${ }^{40}$ While the document requested needs to be identified in "a sufficiently precise manner, to enable the institution to identify the document", the institutions should also assist the applicant in clarifying their application if need be. ${ }^{41}$

But the practice of requesting documents reveals, not surprisingly, a reality different from the citizen engaged in EU decision-making for the sake of democratic scrutiny. The institutional reports on the application of Regulation 1049/2001 reveal that companies, academics and law firms represent a very significant proportion of applicants. According to the Commission's 2018 annual report, these categories combined represented $39,4 \%$ of the total number of initial applications, citizens $42.2 \%$ and journalists $10.1 \%,{ }^{42}$ being that the category "citizens" included applicants who did not identify their social and occupational profile (which is not compulsory). ${ }^{43}$ There is, in fact, no way to know how many citizens, in their quality of citizens, are exercising their fundamental right to access documents of the Commission (not least because this data is collected on the basis of information provided by the applicants, and the institutions may struggle with addressing cases of false identities). ${ }^{44}$ The classification of applicants made by the Council is different but its report reveals a similar picture: $28.8 \%$ of applicants making initial requests in 2018 were academics, followed by $27 \%$ belonging to the "civil society/private sector" category (which includes "consultants", "industrial and commercial sector", NGOs, "other groups of interest",

\footnotetext{
40 Article 2(1) (its paragraph 2 gives the EU institutions the possibility of granting access also to non-residents or to legal persons not legally established in the EU) and Article 6(1) of Regulation 1049/2001.

41 Article 6(2) of Regulation 1049/2001 (see also paragraphs 3 and 4, equally presupposing an active stance on the part of the requested institution). Se, e.g., Case T-436/09, Dufour v ECB, para 29 and 30, where the Court highlights the importance of this provision considering the difficulties that citizens may have in identifying documents and considers this duty (as enshrined in Decision 2004/258/ECB, cit.) a manifestation of the principle of sound administration.

42 Report from the Commission on the application in 2018 of Regulation No. 1049/2001 regarding public access to European Parliament, Council and Commission documents, COM(2019) 356 final, Brussels, 29.7.2019, p. 12. Initial applications refer to the original requests, which, if access is refused, may be followed by a confirmatory application (Article 7(1) and (2) of Regulation 1049/2001).

43 Ibidem, p. 12

${ }^{44}$ Referring to the problem of false identities, see L. ROSSI AND P. VINAGRE E SILVA , op. cit., pp. 43.
} 
“environmental lobbies"), 6,9\% lawyers and 6.4\% journalists. ${ }^{45}$ As for the Parliament, its report of 2018 informs us that: "academics and researchers still represent the largest share of applicants $[\ldots 30 \% \ldots]$, followed by the business sector, environmental organizations and other interest representatives, accounting together for around $12 \%$ of applications." ${ }^{246}$ Tellingly, combined, they form the category "civil society" in the Parliament's classification. It is followed by lawyers (9\%) and journalists $(5 \%)$. While these percentages vary from year to year, the overall picture does not appear to change fundamentally. ${ }^{47}$ Moreover, the industrial sector prevails, by far, and steadily over the years, among litigants who seek a judicial remedy for a perceived violation of their right to access documents of the EU. ${ }^{48}$

The fact that researchers and corporations make a significant part of the requests on access to documents in the EU does not per se deny the democratic function of this right - which the Court keeps on stressing in its case law. ${ }^{49}$ The relevance of industry in the exercise of a fundamental right - as such protected by the Charter, with all the symbolism that may carry - is not a reality that is exclusive of the EU. ${ }^{50}$ But this is a powerful reminder that transparency serves different purposes and is conditioned by "the normative commitments and worldviews of those in a position to invoke it". ${ }^{51}$ This is particularly noteworthy in a polity deprived of the democratic structures of states, where transparency has been one of the carriers of a democratic ethos. Without prejudice to transparency's ability to mould the EU along democratic tenets, it is important to bear in mind that many of the usages of the right of access are at best heedless of a democratic purpose. From this perspective, the regulation on access to documents, as important as it is, contributes to

\footnotetext{
45 Council of the European Union (Working Party on Information), Seventeenth Annual Report of the Council on the implementation of Regulation (EC) No 1049/2001 of the European Parliament and of the Council of 30 May 2001 regarding public access to European Parliament, Council and Commission documents, 7917/19, Brussels, 2 May 2019, p. 13. 12.1\% are "undeclared", 13.9 are "others", which in addition to those mentioned in the text are added to "public authorities (non-EU institutions, third country representatives, etc.)" with $3.4 \%$ of initial requests and "Members of European Parliament and assistants" with 1.5\% of initial requests. The numbers vary for confirmatory applications (see p. 14).

46 European Parliament's Annual Report, “Public Access to Documents 2018”, March 2019, p. 11.

${ }^{47}$ L. LEPPÄVIRTA AND H. DARBISHIRE, « The right to ask... the right to know - the successes and failures in access to documents rules and practices from an NGO perspective » in C. HARLOW, P. LEINO AND G DELLA CANANEA (eds.) Research Handbook on EU Administrative Law (Edward Elgar), 2017, pp. 399-422, at pp. 404-407.

48 L. Rossi AND P. Vinagre E SiLva , op. cit., p. 55-59.

49 See e.g. Judgment of the Court of 4 September 2018, ClientEarth v Commission, Case C-57/16 P, EU:C:2018:660, para. 73 to 75 .

${ }^{50}$ D. E. PozEN, op. cit., pp. 124-127.

${ }^{51}$ D. E. Pozen, op. cit., pp. 146.
} 
shaping a specific type of democracy anchored not on the relationships between citizens and public power, but rather on the relationships between specific interest holders and public powers. ${ }^{52}$

\subsection{The extent of transparency}

Access to documents is not (cannot be) unlimited..$^{53}$ The protection of both public and private legally protected interests may justify withholding access, as specified in Article 4 of Regulation 1049/2001. This is a central provision of the legal regime on access to EU documents, source of a rich case law which, at the end, defines the extent to which access may be granted. The overall scheme of Article 4 envisages two types of exceptions, depending on whether the protection of the competing public or private interest that may justify a refusal of access is subject or not to a public interest test. On the one hand, if access may hinder public interests, such as the protection of international relations, of the financial, monetary or economic policy of the Union or of a Member State, or the protection of the privacy and integrity of the individual, the institutions "shall" refuse access, subject to justification. ${ }^{54}$ On the other hand, the protection of other competing interests (namely: commercial interests, including intellectual property; court proceedings and legal advice; the purpose of inspections, investigations and audits; the institution's decision-making process) only justifies refusal of access subject to an examination of whether an "overriding public interest" could, nonetheless, justify disclosure.$^{55}$ It is the applicant who needs to invoke the "specific circumstances" that can establish the existence of such an interest and show how disclosure would contribute to its protection. ${ }^{56}$ This is a hurdle that is virtually impossible to overcome, in particular given that at the time in which the applicant needs to make this demonstration the content of the document is not publicly known. According to the case law, reasons of transparency can constitute such overriding public interest, but general considerations

\footnotetext{
52 H. MiCHEL, op. cit..

53 That follows from Article 15(3) TFEU: although the "conditions" of access that need to established by a regulation do not need to include exceptions, it is submitted that full transparency without limits is not feasible given the possible breach of competing rights. This very normative assertion - access cannot be unlimited - was contested in Judgment of 30 January 2020, CBA Spielapparate- Restarantbetrieb GMbH v Commission, Case T-168/17, EU:T:2020:20. Here, the applicant submitted that "the exceptions provided for in Article 4 of Regulation (EC) No 1049/2001 are unlawful, since they conflict with higher-ranking primary law, in particular with Articles 42 and 47 of the Charter of Fundamental Rights of the European Union". The applicant further claimed that, given this conflict between primary and secondary law, the Commission should not have applied the exceptions established in the access to documents regulation. Both the Council and the Parliament have intervened in support of the European Commission (Order of 18 May 2018 in CBA v. Commission, Case T-168/17, para 6) and the Court easily dismissed the applicant's plea (para 65 to 69).

54 Article 4(1) of Regulation 1049/2001.

55 Article 4(2) and (3) of Regulation 1049/2001.

${ }^{56}$ E.g. Judgment of 7 February 2018, Access Info Europe v Commission, Case T-852/16, EU:T:2018:71, para 97; CBAv Commission, para 55 and 56.
} 
do not suffice. ${ }^{57}$ At least judging from the case law in the already long life of Regulation 1049/2001, the possibility of establishing "an overriding public interest" appears to be dead letter.$^{58}$ Common to both types of exceptions is the duty of the institution requested to consider the possibility of giving partial access. ${ }^{59}$

The way the functioning of the exceptions is interpreted, arguably, determines the extent to which the regulation may fulfil its democratic aims. In this regard, the Court of Justice has followed two quite distinct approaches, which reflect a different weighing of the interests of disclosure and of confidentiality. On the one hand, in line with the democratic rationale of this right and, specifically, with the principle of widest possible access to public documents, it has consistently held that the exceptions must be "interpreted and applied strictly". ${ }^{60}$ On the other hand, the Court has admitted that the institutions may rely on general presumptions of nondisclosure, applying to certain categories of documents, to justify applying one of the exceptions established in Article 4. This divide remains one of the core features of the case law regarding access to documents and will be explained in more detail below, not least because (as will be argued) it also results from the tension between the functional and the democratic character of the EU and confirms that access to documents needs to be analyzed in this specific context.

\section{A. Beyond a strict interpretation of the exceptions: the first steps of general presumptions of non-disclosure}

In Sweden and Turco $v$ Council, a judgment pertaining to the interpretation of the exception legal advice with regard to a request of access to a legal opinion of the Council's legal service, the Court of Justice, deciding in grand chamber, established with all clarity a tripartite test that, in line with the principle of strict interpretation of the exceptions, the institutions must follow when examining

\footnotetext{
${ }^{57}$ E.g. Sweden and Turco $v$ Council, para 45 (referring to "the public interest in the document being made accessible in the light of the advantages stemming... from increased openness"); Access Info Europe v Commission, T-851/16, EU:T:2018:69, para 98; Liam Campbell v Commission, Case T-312/17, EU:T:2018:876, para. 64; and Loreto Sumner v Commission, Case T-152/17, EU:T:2018:875, para. 64.

58 L. Rossi AND P. Vinagre E Silva op. cit., pp. 159, pointing out that "to date there has been no successful identification of any [overriding public interest] by the applicant”. See too, D. ADAMSKI, « Approximating a Workable Compromise on Access to Official Documents: The 2011 Developments in the European Courts » Common Market Law Review, Vol. 49, 2012, pp. 521-558, p. 526 and 543. Holding that the "public interest in question must be exceptional and pressing" given its function, see Opinion of AG HOGAN delivered on 11 September 2019 in PTC Therapeutics Ltd v European Medicines Agency (EMA), Case C-175/18 P, EU:C:2019:709, para 123 and 128. Equally restrictive, see $C B A v$ Commission, para 55 and 56.

59 Article 4(6) Regulation 1049/2001. See, further, L. Rossi AND P. VINAGRE E SiLVA op. cit., pp. 147-151.

${ }^{60}$ E.g. Sison v Council, Case C-266/05 P, EU:C:2007:75, para 63; Sweden v Commission, Case C-64/05 P, para 66; Sweden and Turco v Council, para 36; Sweden and Others v API and Commission, para 73; Sweden v Commission and MyTravel Case C-506/08 P, EU:C:2011:496, , para 75; Case C-57/16 P, ClientEarth v Commission [2018], para 78.
} 
a request on access to documents. ${ }^{61}$ In order to assess whether the document requested falls within one of the exceptions, the institution must: first, "satisfy itself that the document which it is asked to disclose does indeed relate to [the pertinent exception] and, if so, it must decide which parts of it are actually concerned and may, therefore, be covered by that exception", calling on the institution to examine the content of the document beyond the way it is named; ${ }^{62}$ secondly, the institution "must examine whether disclosure of the parts of the document in question which have been identified as relating to [a specific exception] 'would undermine the protection' of [the interest protected]", specifying that "the risk of that interest being undermined must, in order to be capable of being relied on, be reasonably foreseeable and not purely bypothetical'; ${ }^{63}$ thirdly, in the case of an exception subject to the public interest test, once the risk of harm to the protected interest has been established, the institution must "ascertain whether there is any overriding public interest justifying disclosure despite the fact that [the interest protected] would thereby be undermined", balancing therefore the two competing interests that point in opposite directions: secrecy and disclosure. $^{64}$

The requirement of establishing a reasonably foreseeable and not purely hypothetical risk in disclosure is set aside in the, by now, extensive number of cases where the institutions are allowed to invoke a general presumption of non-disclosure. Where such a presumption applies, the institution concerned does not have a duty to examine specifically and individually the

\footnotetext{
${ }^{61}$ But also laid down the seed for the subsequent case law on general presumptions: Sweden and Turco v Council, para 50 (as noted by L. Rossi And P. Vinagre e Silva op. cit., p. 154). See too Judgement of 29 June 2010, Commission v Technische Glaswerke Ilmenau, C 139/07 P, EU:C:2010:376, para 54.

${ }^{2}$ Sweden and Turco v Council, para 38 and 39 ("over and above the way a document is described, it is for the institution to satisfy itself that that document does indeed concern such advice”).

63 Sweden and Turco $v$ Council, para 40 and 43, emphasis added. The regulation indicates that a different standard of harm applies to the exceptions of paragraphs 1 and 2 of Article 4 (access shall be denied when "disclosure would undermine the protection" of the interests specified therein), on the one hand, and to the exceptions of paragraph 3 of the same article (where access shall be denied if "disclosure would seriously undermine the protection" of the institution's decision-making process; emphasis added). See, in this respect, Judgment of 22 January 2020, PTC Therapeutics International Ltd $v$ EMA, C-175/18 P, EU:C:2020:23, para 90 and Opinion of AG HOGAN in PTC Therapeutics $v$ EMA, cit., para 104 to 110$)$.

64 Sweden and Turco $v$ Council, para 44 and 45. On the importance of keeping the second and third step separate, in line with the scheme of the exceptions of Article 4(2) and (3), criticizing subsequent case law (specifically, Judgments of 17 October 2013, Council v Access Info Europe, C-280/11 P, EU:C:2013:671, and of 3 July 2014, Council v in't Veld, C-350/12 P, EU:C:2014:2039) for failing to do so, and suggesting that the Court should clarify this matter, see Opinion of AG HOGAN in PTC Therapeutics $v$ EMA, cit., para 115 to 119, 121, 127 and 128. For an example of other judgments where the Court has ruled that the weighing of interests takes place at the second stage, see Case T-852/16, Access Info Europe (EU Turkey Agreement), para 61, following the judgments that, according to AG HoGAN, stand to be corrected. The Court, however, did not seem to see reason for correction (referring neither explicitly to the opinion, nor to the case law mentioned therein) and upholding the General Court on the relevant point (PTC Therapeutics $v$ $E M A$, para 86).
} 
documents requested. Such a duty would, in fact, render the general presumption ineffective. ${ }^{65}$ In this second line of cases, the Court started off by shielding specific legal regimes of access to documents - set out in sector or, otherwise, specific laws ruling access to the file in state aids procedures, merger control, tender procedures (to which the general EU financial regulation applies), cartels, competition infringement procedures, or rules governing proceedings before the EU courts - from the impact that access granted under Regulation 1049/2001 to persons otherwise blocked therefrom could have on the respective procedure. ${ }^{66}$ In doing so, it also, arguably, shielded the regime of public access to documents from applicants (and litigants) that sought, thereby, to circumvent the limits on access to administrative files set out in specific legislation. Thus, in a state aid procedure, on appeal lodged by the Commission and judging again in grand chamber format, the Court of Justice held that the institutions may rely, for refusal of disclosure, on general presumptions applicable to "certain categories of documents", on the grounds that "considerations of a generally similar kind are likely to apply to requests for disclosure relating to documents of the same nature". ${ }^{67}$ This was the first of many other cases where a general presumption could be inferred from the existence of sectoral law that defines, in each instance, the conditions under which the documents pertaining to an administrative file may be accessed. ${ }^{68}$ If persons interested in the procedure, who are not entitled to obtain access to the file under sector law - in this case, state aid law - would be given access on the basis of Regulation 1049/2001, "the system for the review of state aid would be called into question". ${ }^{69}$ It is, hence, the nature of the procedure that is in question, as the Court explains:

\footnotetext{
${ }^{65}$ Judgment of 14 November 2013, LPN and Finland v Commission, C-514/11 P and C-605/11 P, EU:C:2013:738, paragraph 83; reiterated, inter alia, at: Judgement of 11 May 2017, Case C-562/14 P, Sweden v Commission, EU:C:2017:356 (Spirlea), para 47; Judgment of 4 September 2018, C-57/16 P, ClientEarth v Commission, para 52; PTC Therapeutics $v E M A$, para 59. This has natural implications for the content of the statement of reasons of a decision to refuse access, which does not presuppose an examination of the documents requested: see Judgment of the General Court of 14 May 2019, Case T-751/17, Commune de Fessenheim and Others v Commission, EU:T:2019:330 para 69 to 76.

${ }^{66}$ See, respectively, Judgment of 29 June 2010, Commission v Technische Glaswerke Ilmenau, Case C-139/07 P (state aids); Judgment of 28 June 2012, Commission v Éditions Odile Jacob, Case C-404/10 P, EU:C:2012:393 (merger control); Judgment of 29 January 2013, Joined Cases T-339/10 and T-532/10, Cosepuri v EFS A, T-339/10, EU:T:2013:38 (tenders); Judgment of 27 February 2014, Commission v EnBW, C-365/12 P, EU:C:2014:112 (competition infringement procedures); Judgment of 21 September 2010, Sweden and Others v API and Commission, C-514/07 P, C-528/07 P and C-532/07 P, EU:C:2010:541 (rules applicable to Court procedures).

${ }^{67}$ Technische Glaswerke Ilmenau, para 54, citing the possibility that Sweden and Turco had left open (see above footnote 61)

${ }^{68}$ Technische Glaswerke Ilmenau, para 55 to 58. For other judgments where specific legislation was at stake, see further references above (footnote 66). Defending the non-recognition of general presumptions in cases where such legislation was absent, see Opinion AG VILLALlón delivered on 16 May 2013 in Case C-280/11 P, Council v Access Info Europe, EU:C:2013:325, para 75, and Opinion AG SHARPSTON delivered on 17 November 2016 in Case C-562/14 P, Sweden v Commission, (Spirlea), EU:C:2016:885, para 40.

${ }^{69}$ Technische Glaswerke Ilmenau, para 58, emphasis added.
} 
"It is true that the right to consult the administrative file in the context of a [State aid] review procedure (...) and the right of access to documents, pursuant to Regulation No 1049/2001 are legally distinct, but the fact remains that they lead to a comparable situation from a practical point of view. Whatever the legal basis on which it is granted, access to the file enables the interested parties to obtain all the observations and documents submitted to the Commission, and, where appropriate, adopt a position on those matters in their own observations, which is likely to modify the nature of such a procedure." ${ }^{70}$

The Court is, hereby, recognizing the power shifts that ensue from transparency and, at the same time, acknowledging that, the specific context in which the right of access to documents is exercised - "the particular circumstances of the individual case" that the Commission had invoked in this case $\mathrm{e}^{71}$ - matters for the decision on whether to grant access or not. This is, however, a very fine thread to straddle on. The potential to restrict, by this very logic, the possibility of citizens or non-for-profit interest groups to improve the transparency of the institutions procedures is large, as shown as the case law evolved and extended the scope of general presumptions to instances where no specific legislation applied. ${ }^{72}$

The judgment in Technische Glaswerke Ilmenau set two other important precedents. First, the Court distinguished the cases in which the institutions "act in the capacity of a legislature, in which wider access to documents should be authorized pursuant to recital 6 of Regulation No 1049/2001, as was the case in Sweden and Turco v Council' from cases in which they act "within the framework of administrative functions specifically allocated to the said institutions [in this case] by Article 88 EC" ${ }^{73}$ It, thereby, consolidated a diving line that Turco started to draw.

Secondly, the Court specified - and has done ever since in cases where it admits general presumptions of non-disclosure - that the applicant has the possibility to demonstrate that the document withheld is not covered by the presumption, or, that, in the case of the exceptions of Article 4(2) and (3) that there is an "overriding public interest" justifying disclosure. ${ }^{74}$ Not only

\footnotetext{
70 Technische Glaswerke Ilmenau, para 59.

71 Technische Glaswerke Ilmenau, para 41 and 42.

72 Examples where citizens or non-for-profit interest groups have been denied access in such circumstances are the judgments in C 514/11 P and C 605/11 P, LPN and Finland v Commission, EU:C:2013:738, which has become settled case law in infringement procedures (see, further, Section 4.2 below); Case C-562/14 P, Sweden v Commission (Spirlea), EU:C:2017:356 (see footnote 126, below); Judgment of 13 November 2015, ClientEarth v Commission, Joined Cases T424/14 and T-425/14, EU:T:2015:848 (admitting a general presumption covering documents produced in impact assessment procedures, and set aside on appeal by Judgment of 4 September 2018, C-57/16 P, ClientEarth v Commission; see, further, Section 4.1 below).

${ }^{73}$ Technische Glaswerke Ilmenau, para 60.

74 Technische Glaswerke Ilmenau, para 62. C-514/11 P and C-605/11 P, LPN and Finland v Commission, EU:C:2013:738, paragraph 66 and 94; Case C-562/14 P, Sweden v Commission, EU:C:2017:356 (Spirlea), para 46 and para where this possibility is examined (para 55 to 59); Association Justice \& Environment v Commission, Case T-727/15, EU:T:2017:18
} 
this places a burden of proof on the applicant which Regulation 1049/2001 has not envisaged, ${ }^{75}$ but also, considering that the applicant has not had access to the document, the threshold placed by the Court amounts to a probatio diabolica. The Court has equated the rebuttal of the presumption with the demonstration of the existence of an overriding public interest, where exceptions of Article 4(2) and Article 4(3) are at stake. ${ }^{76}$ In a case where the applicant sought access to documents produced in an environmental infringement procedure, with the purpose (which it needs not state) of securing public consultation in a national administrative procedure on air pollution plans, the Court held that "it is for the applicant to demonstrate precisely in what way disclosure of the documents at issue would contribute to assuring protection of human health and the environment and would prevail in the present case over protection of the purpose of the investigations in [that specific] infringement procedure". ${ }^{77}$ General considerations do not suffice, effectively blocking, contrary to the Court's assessment, access to documents in cases where general presumptions are invoked. $^{78}$

\section{B. Between the 'specific circumstances of the case at hand' and matters of principle}

Most commentators have, rightly, denounced this line of case law as contrary to the spirit of the regulation, that is, as contrary to its democratic rationale and as excessively and non-justifiably curbing a fundamental right. ${ }^{79}$ Yet, as indicated above, the case law justifies a more nuanced analysis. The Court is correct in seeking to strike a balance between the regime of public access to

para. 48 and 49 (stressing, at para 80, that "the case-law has already established that the existence of certain general presumptions does not result in depriving the right of access to documents of all practical effect, given that the general presumptions at issue are not irrefutable").

75 P. Leino, "Just a Little Sunshine in the Rain: The 2010 Case Law of the European Court of Justice on Access to Documents" Common Market Law Review, Vol. 48, 2011, 1215, at 1251.

${ }^{76}$ LPN and Finland $v$ Commission, cit., para 66.

77 Case T-727/15, Association Justice \& Environment v Commission, para 52. The applicant had stated that it was "not in a position to prove what concrete information contained in the requested documents could specifically be used to improve these problems of air pollution" (para 21) and asked the Court to revise its case law in cases pertaining to information on environmental infringement procedures, for the sake of transparency (para 35 to 37 ; see in this regard, para 67 to 79$)$.

${ }^{78}$ Ibidem, para 53 to 62. See, further, L. Rossi AND P. VINAGRE E SilVA op. cit., pp. 160-163. For a recent example, see $C B A v$ Commission, para 52 to 62.

79 See, e.g. O. Brouwer And J. BlockX, « Access to Documents Relating to EU Competition and State Aid Cases Pursuant to Regulation 1049/2001: Towards a Rebuttable Presumption as a "Fig Leaf" for Intransparency?, in Baumé/Elferink/Phon/Thiaville (Hrsg.), Today's Multilayered Legal Order: Current Issues and Perspective: Liber Amicorum in Honour of Arjen W.H. Meij, Paris, 2011, p. 39, at p. 49; A.M. KOPpenSTEINER, " Die Transparenzverordnung im Wandel der Zeit », Europarecht 2014, 594, p. 602-605, calling for a consideration of the limits of general presumptions in the revision of the regulation on access to documents; D. CURTIN and P. LEINO, « Openness, Transparency and the Right of Access to Documents in the EU », p. 9-12. 
documents, on the one hand, and specific procedural regimes established by the legislature. The latter have been defined, presumably, on the basis of a careful consideration of the conditions that ensure both the legitimacy and the effectiveness of the procedure. General presumptions may tip the balance too much in favour of the protection of the nature of the procedure, dismissing all too easily any considerations that could be drawn from the democratic rationale of access to documents. They effectively have had this result and should be criticized from this perspective. ${ }^{80}$ But the need to make this balance, at the stage of verifying the applicability of the exception, is a defensible stance, when backed by (sector) rules adopted through a legislative procedure. It is not excluded that general presumptions can be a good outcome of such balance. The grounds for such general presumption are, however, much shakier when there are no such specific legal rules on access to a file, or when such rules are soft law rules enacted by the very institution that can rely on general presumptions. Such is the case of Commission infringement procedures, where effective access to documents is, by force of the application of general presumptions, virtually in the sole hands of the institution (at least as the case law stands hitherto). As will be seen in more detail below, the application of general presumptions to the Commission infringement procedures is, in part for this reason, a step too far in the direction of confidentiality of public documents.

It is equally problematic that there is currently a significant uncertainty regarding the criteria governing the recognition of these presumptions and the way they are applied. ${ }^{81}$ This is all the more worrying when, more recently, the Court of Justice made clear that the application of a general presumption is "always optional for the EU institution, body, office or agency". 82 Combined with the lack of criteria mentioned, this stance leaves the scope of access in the hands of the requested institution or body. The existence of specific rules (from which may be derived the need to protect the nature of the procedure from access to documents granted under Regulation 1049/2001) is no longer a necessary condition for the recognition of a general presumption, since the Court of Justice first recognized the application of general presumptions

\footnotetext{
${ }^{80}$ Depending on how they are applied, they potentially withdraw whole categories of documents from the scope of Regulation 1049/2001. In addition to the probation diabolica mentioned above, the way the Court has ruled pleas of partial access in cases where it has recognised the general presumption confirms this conclusion: see, e.g. Commission v Éditions Odile Jacob, cit., paragraph 133, holding that the general presumption indicates "that the documents covered by [the exceptions] do not fall within an obligation of disclosure, in full or in part, of their content", reiterated, inter alia, at Case T-312/17, Liam Campbell v Commission, para 47.

${ }^{81}$ For a reflection of this uncertainty, see the diverging views of the General Court and of the parties manifested in the Opinion of AG HOGAN in PTC Therapentics v EMA, cit., para 25 and 45 to 50. At stake was the possibility to extend the case law on general presumptions to clinical study reports that are part of the procedure to obtain a market authorization of pharmaceutical products.
}

82 PTC Therapeutics International Ltd $v$ EMA, para 61 and 62 (emphasis added). 
to EU Pilot procedures' documents, in the context of EU law infringements. ${ }^{83}$ Necessary conditions appear to be, to date, the existence of a set of documents pertaining to a file relating to ongoing administrative or judicial proceedings, involving only specific categories of procedures. ${ }^{84}$ But it is not excluded that other categories of general presumptions may be recognised. ${ }^{85}$ On which grounds - whether prudential (to prevent a lower degree of protection of the interests covered by the exceptions of Article 4) or normative (to preserve the democratic function of the rules on access to documents) - remains unclear, but, at present, prudential reasons seem to prevail. ${ }^{86}$ The prediction of AG Sharpston in the Spirlea case, associating, on the one hand, the absence of specific rules governing a procedure and, on the other, the uncertain scope of "any exception to the general principle of transparency" based on the purpose and nature of the procedure, appears to have materialized. ${ }^{87}$

A minimum condition to prevent general presumptions from withdrawing whole categories of documents from the scope of Regulation 1049/2001 is to impede their automatic application to each category of documents already covered by such presumptions. ${ }^{88}$ They are, as the Court admits, an exception to the rule of strict interpretation of the exceptions to access, which the regulation postulates, and need to be maintained as such. In each case, the Court ought to carefully consider the position of the requesting "citizen" (any person using Regulation 1049/2001 is, as matter of law, acting in that quality) and the relevance of the democratic rationale of the regime of public access to documents in the circumstances in which it is called upon to decide. As such, the reiteration of the fact that "the institution concerned is not required to base its decision on a general presumption", where this has been previously established ${ }^{89}$ is of little avail to prevent the systematic application of general presumptions where they have been previously recognized. The fact that the decision of applying a general presumption is a faculty of the institution ("always optional", as the Court of Justice clarified) leaves the door open to such systematic application on the part of the institutions, bodies, offices and agencies.

\footnotetext{
83 Sweden v Commission (Spirlea), cit., para 44 and 45.

${ }^{84}$ E.g Case T-540/15, De Capitani v Parliament, para 82, stating that the number of documents is not a decisive criterion. 85 In this sense, Opinion of AG HOGAN in PTC Therapeutics v EMA, cit., para 65.

86 That much results from Client Earth as applied by AG HoGAN in its opinion PTC Therapeutics v EMA, cit., para 78 to 80 (on Client Earth see further below, section 4.1).

87 Opinion AG SHARPSTON in Sweden v Commission (Spirlea), cit., para 51.

88 Sweden and Turco v Council, para 50. For a concrete application see Judgment of 4 October 2018, Daimler AGv Commission, Case T-128/14, EU:T:2018:643, para 152 to 164.

89 The argument is that the institution may always choose to carry out a specific examination of the requested documents and take a decision on that basis. See, inter alia, in Commission v Technische Glaswerke Ilmenau, paragraph 62; Sweden and Others $\mathrm{v}$ API and Commission, paragraph 103; Commission v Éditions Odile Jacob, paragraph 126; LPN and Finland $v$ Commission, para 67. See, in addition, PTC Therapeutics International Ltd $v$ EMA, para 61 and 62.
} 
A closer examination of how the Courts have interpreted some of the exceptions will show the fields of activity of the EU that the institutions have hitherto sought to carve out from the principle of transparency. To the extent the Courts admitted, they have been insulated from the developments that have placed EU decision-making under the pressure of democratic claims. The analysis below also allows us to get a better sense of how the institutions perceive the role of transparency in specific procedures (whether or not this is shared by the Courts), and, in given cases, of the criteria governing the application of general presumptions of non-disclosure.

\section{Some concrete borderlines between democracy and confidentiality}

\subsection{Legislative and administrative documents}

The judgments in Sweden and Turco and in Technische Glaswerke Ilmenau have generated a distinction in the case law between documents produced in the context of legislative procedures, with regard to which the principle of democracy requires a more favourable regime of access, and those produced in the context of administrative procedures, where reasons of democracy are not as pressing or at all applicable. In Sweden and Turco, the Court stressed that increased transparency, citizens' closer participation in EU decision-making processes, legitimacy and accountability to the citizen "are clearly of particular relevance where [the institutions are] acting in [their] legislative capacity". ${ }^{0}$ In Technische Glaswerke Ilmenau, the Court noted the contrast between, on the one hand, situations "where the Community institutions act in the capacity of a legislature, in which wider access to documents should be authorised pursuant to recital 6 of Regulation No 1049/2001", and, on the other, documents that "fall within the framework of administrative functions". ${ }^{11}$ This distinction became further entrenched as the case law on general presumptions evolved. ${ }^{92}$

It is noteworthy that, although the regulation and primary law attach particular importance to the principle of transparency in the case of legislative procedures (as the Court has emphasized in several occasions), ${ }^{93}$ the regulation also establishes one single regime of access to documents,

\footnotetext{
90 Sweden and Turco v Council, para 45 and 46. See too C-280/11 P, Councilv Access Info Europe, para 33 and 63 (but see para 72 to 74 , leaving open the possibility that a general presumption could apply in the context of a legislative procedure).

91 Technische Glaswerke Ilmenau, para 60. See also Judgment of 21 September 2010, Sweden and Others v API and Commission, C-514/07 P, C-528/07 P and C-532/07 P, EU:C:2010:541, para 77. Not long thereafter, in My Travel, AG КОКОTT held that "administrative activities do not require the same breadth of access to documents as legislative activities of the EU institutions" (Opinion delivered on 3 March 2011, in Case C-506/08 P, Sweden v Commission, para 60). The General Court had adopted the same position in the judgment at first, a few months after the Court of Justice had pronounced its Turco judgement (MyTravel v Commission, Case T-403/05, para 49).

92 E.g. Client Earth v Commission, Case C-612/13 P, para 78.

93 Article 15(2) TFEU, recital 6 and Article 12(2) of Regulation 1049/2001.
} 
without distinction. For this reason, the lower transparency currently afforded to administrative documents can be considered incompatible with the regulation. ${ }^{94}$ But the unitary character of the legal regime of Regulation 1049/2001, read in the light of the current case law, can also still be the ground to declare a general presumption with regard to documents of a legislative nature. This possibility is, admittedly, remote, as it would require the Court to overrule a significant part of its stance in Turco and following case law, where it has always stressed the special position of legislative documents. It would, furthermore, be deeply problematic, considering the above critique of general presumptions. Yet, formally, it is a possibility that does not appear to be fully ruled out. ${ }^{95}$ The judgment in De Capitani, pertaining to a request of access to documents produced in the context of trialogues, and an important hallmark regarding one controversial aspect of the EU legislative procedures, ${ }^{96}$ is illustrative in this respect.

As in previous cases, also in De Capitani, the General Court, relying on the democratic relevance of transparency in legislative procedures, singled out the specificity of legislative documents that, as a matter of principle, would make the recognition of a general presumption impossible in such cases. "The principles of publicity and transparency", the Court held, are "inherent to the EU legislative process", by force of both primary law and of the regulation on access to documents. ${ }^{97}$ The Court, therefore, made clear that, for this reason, considerations of effectiveness of the legislative procedure cannot justify secrecy. ${ }^{98}$ Accordingly, those same principles preclude the application of a general presumption. ${ }^{99}$ But the General Court refrained from such a principled statement. It noted, instead, that the Court of Justice has never recognized a general presumption with regard to legislative documents. ${ }^{100}$ It further emphasized that general presumptions have been recognized always with regard to "specific proceedings" and not to a general category of documents. In the case at hand, applying a presumption to documents produced in trialogues could "cover, by definition, all fields of legislative activity". ${ }^{101}$ In this line of

\footnotetext{
94 D. CURTIN and P. LEINO, «Openness, Transparency and the Right of Access to Documents in the EU. InDepth Analysis for the PETI Committee », 2016, p. 9-12.

95 Councilv Access Info Europe, Case C-280/11 P, para 72 to 74, as noted in footnote 90 above.

96 See D. CURTIN and P. LEINO, «In Search for Transparency in EU Lawmaking: Trilogues in the Cusp of Dawn», Common Market Law Review, Vol. 54, 2017, 1673-1712.

97 Case T-540/15, De Capitani v Parliament, para 81 and 78 to 80.

98 De Capitani v Parliament, para 83, 98, 99, 103 and 105.

99 AG BOT made such a principled statement in his opinion in C-57/16 P, ClientEarth (not, as such, repeated by the Court), associating the need to provide wider access to impact assessments and the respective reports (given their intrinsic link to a legislative procedure) with the preclusion of a general presumption (para 69).

100 De Capitani v Parliament, para 82

${ }^{101}$ De Capitani v Parliament, para 109.
} 
reasoning, the specificity of the procedure - rather than the democratic principle of transparency underlining legislative procedures - remains a decisive criterion. Undoubtedly, the specific importance of transparency with regard to legislative procedures is a strong argument to deny the application of general presumptions in this context. Yet, the Courts (unlike the Advocate Generals) have not yet made such a principled statement, having had that opportunity. ${ }^{102}$

The fact remains that, as stated in de Capitani, the Courts hitherto have always refused to place legislative documents under the scope of general presumptions of non-disclosure. The special position that "decisions" and "decision-making process" acquire in the context of a legislative procedure, ${ }^{103}$ ultimately raises the issue of what counts as a legislative and as an administrative document, or when an institution is acting in one or the other capacity. The question arose with regard to documents produced during impact assessment procedures. In ClientEarth, the General Court held that the Commission does not act in a legislative capacity when it prepares or develops a proposal for an act, "even a legislative act", with the result that the democratic rationale of disclosure in legislative procedures did not preclude the application of a general presumption of non-disclosure to draft impact assessment reports (and to the related reports of the Impact Assessment Board). ${ }^{104}$ The Court of Justice, judging on appeal, decided otherwise. Legislative documents are, in accordance with Article 12(2) of the Regulation 1049/2001, "documents drawn up or received in the course of procedures for the adoption of acts which are legally binding in or for the Member States". ${ }^{105}$ Even if in the phase leading up to the adoption of a legislative proposal the Commission does not act in a legislative capacity, the Commission is a "key player in the legislative process" by virtue of the powers of initiative that the Treaty gave it and the documents produced during impact assessments contain "important elements of the EU legislative process". ${ }^{106}$ These documents benefit, therefore, from the wider access that the regulation recognized to legislative documents. The Court of Justice noted as well that "the impact assessment procedure is not a type of procedure which, as such, has features that preclude in principle full transparency". ${ }^{107}$ In this case, the general considerations on which the General Court

\footnotetext{
102 See Opinion of AG BOT in C-57/16 P, ClientEarth, para 64, pointing the nature of the document as a decisive for the application of a wider access to documents (in that case, it was contraposed not to the specificity of the procedure as an additional criterion, but to the capacity - legislative or otherwise - in which an institution acts).

103 De Capitani v Parliament, para 79.

104 General Court ClientEarth v Commission, para 102-103.

105 ClientEarth v Commission, para 85.

106 ClientEarth v Commission, para 86 to 88 and 91.

${ }^{107}$ ClientEarth v Commission, para 103.
} 
grounded the recognition of a general presumption did not support the finding of a risk to the Commission's decision-making process. ${ }^{108}$

This conclusion was in conformity with the Court of Justice's statement of principle regarding the recognition of a general presumption "in respect of a new category of documents": the institution invoking a presumption ought first to show "that it is reasonably foreseeable that disclosure of the type of document falling within that category would be liable actually to undermine the interest protected by the exception in question". ${ }^{109}$ The Court took the opportunity to clarify that "such a risk depends on factors such as the state of completion of the document in question and the precise stage of the decision-making process in question at the time when access to that document is refused, the specific context in which that process takes place, and the issues still to be discussed internally by the institution concerned." ${ }^{110}$ Once again, an EU Court - this time the Court of Justice deciding in grand chamber - refrained from a principled statement that general presumptions of non-disclosure are not applicable to legislative documents, while not failing to stress, once again, the particular importance of transparency in legislative procedures. ${ }^{111}$

\subsection{Infringement procedures}

Infringement procedures occupy a "special position within the system of access to documents". 112 Although with deeper roots in the case law, ${ }^{113}$ such principled position was clearly stated in the $L P N$ judgment, where for the first time the Court of Justice extended the case law on general presumptions to the pre-litigation procedures conducted under Article 258 TFEU. ${ }^{114}$ It did so by upholding the judgment of the General Court, which had relied on an argument of analogy with the Technische Glaswerke Ilmenau judgment on state aids procedures. ${ }^{115}$ The applicant had requested "a set of documents, described as a whole, appearing in the file relating to the infringement procedure", which was still ongoing. ${ }^{116}$ The conditions to transpose the general presumption that

\footnotetext{
108 ClientEarth v Commission, para 105, 108, 110.

109 ClientEarth $v$ Commission, para 80. As mentioned above, it is on this basis that AG HoGAN has more recently proposed the extension of a general presumption to a new category of non-legislative documents (see above footnotes 85 and 86).

110 ClientEarth v Commission, para 111.

111 Notably at ClientEarth $v$ Commission, para 104 and

${ }^{112}$ LPN and Finland $v$ Commission, C 514/11 P and C 605/11 P, EU:C:2013:738, para 55. Reiterated in Case T-312/17, Liam Campbell v Commission, para 32 and in Case T-152/17, Loreto Sumner v Commission, EU:T:2018:875, para 34.

113 D. ADAMSKI (2009) «How Wide is the "Widest Possible"? Judicial Interpretation of the Exceptions to Right of Access to Official Documents Revisited », Vol. 46 Common Market Law Review, pp 521-549, at pp. 538-41.

114 See references in footnote 112

115 Cite GC *** paras 126 and following.

${ }^{116}$ LPN and Finland $v$ Commission, para 49 and 50 (see, also, Case T-727/15, Association Justice \& Environment, para 45).
} 
the Court had defended in previous cases were fulfilled. ${ }^{117}$ It is noteworthy, however, that the applicant was an association constituted under Portuguese law established with the objective to protect the environment. That same association had been monitoring compliance by a Member State with EU law on biodiversity and was at the origin of the complaint leading to the infringement procedure in that instance.

The arguments were three-fold, all upholding the special position of infringement procedures. First, these have "characteristics [that preclude] full transparency". ${ }^{118}$ This argument was made based on a norm of the Aarhus regulation that excludes infringement procedures from boarder access to environmental information. Yet, the General Court has later on ruled that the existence of a specific set of legislative provisions providing for stricter rules of access to documents is irrelevant for the application of a general presumption. ${ }^{119}$ Second, the Court held that those characteristics are similar to the ones of stated aid review procedures at stake in the Technische Glaswerke Ilmenau judgment: there is a bilateral procedure involving the Member State investigated and the Commission, in relation to which EU law does not recognize a "right for an individual to consult the file", regardless of that individual being the complainant that initiated the infringement procedure. ${ }^{120}$ Thirdly, this is a procedure characterized by the discretion of the Commission with the double purpose of allowing the Member State to defend itself and enabling an agreement that can put an end to the putative infringement. ${ }^{121}$ Therefore, the Court concluded: "the disclosure of the documents concerning an infringement procedure during its pre-litigation stage would $\ldots$ be likely to change the nature and progress of that procedure, given that, in those circumstances, it could prove even more difficult to begin a process of negotiation and to reach an agreement between the Commission and the Member State concerned putting an end to the infringement alleged, in order to enable European Union law to be respected and to avoid legal proceedings". ${ }^{122}$ Disclosure of documents during an infringement procedure is detrimental to the "climate of trust" that needs to exist between the two parties concerned - the Commission and

117 LPN and Finland $v$ Commission, para 47. On the conditions for the application of the presumption, see further C-612/13 P, ClientEarth v Commission, EU:C:2015:486, para 59 to 63 (regarding the concept of "investigations"), 70 (regarding the categories of documents) and para 79 (delimiting the scope of those documents).

${ }^{118}$ LPN and Finland $v$ Commission, para 55.

119 Liam Campbell v Commission, para 33 and Loreto Sumner v Commission, para 35.

${ }^{120}$ LPN and Finland $v$ Commission, para 56 to 60.

${ }^{121}$ LPN and Finland $v$ Commission, para 61 and 62.

${ }^{122}$ LPN and Finland $v$ Commission, para 63, emphasis added (see, also, Case T-727/15, Association Justice \& Environment, para 46). 
the Member State - to facilitate the adoption of a "consensual solution" in case of a detection of an infringement procedure. ${ }^{123}$ This has been settled case law since. ${ }^{124}$

This special nature of the procedure - as established by the Court - is the key of the judgment, and of other rulings that confirmed the Court's position in LPN. The ground for the general presumption is neither the need to reconcile different regimes of access to information, nor, in reality, an argument of analogy with state aid review procedures, but the shielding of a procedure that has kept its diplomatic nature since the very beginning of EU integration. ${ }^{125}$ The exclusion of access to documents in infringement procedures, as an effect of the general application of a general presumption of confidentiality, shows clearly the hard borders of democratic arguments in EU law. No argument regarding the public interest character of the request made, or the special position of environmental associations to ensure compliance with environmental law (as international and EU law acknowledge), or the fact that at stake is the protection of diffuse rights of the EU citizens and the public enforcement of those rights, is capable of overriding the confidential nature of EU infringement procedures as they have originally been designed in EU law. That much is confirmed in subsequent case law (in Spirlea, Client Earth, and Association Justice \& Environment). ${ }^{126}$ The Court considered the purpose of the request (i.e. supplementing the information held by the Commission on the infringement at stake) irrelevant to the effect of establishing an overriding public interest that could have justified disclosure. ${ }^{127}$ The fact that it required LPN to rely on specific circumstances to prove the presence of an overriding public interest - something it arguably could not have proven without having access to the documents it

${ }^{123}$ C-612/13 P, ClientEarth v Commission, EU:C:2015:486, para 70, 72 (drawing on the judgment in LPN) and 75.

124 See the cases mentioned in footnotes 112 and 116.

125 Despite the evolution of procedural rules - see, in this regard, and making a different argument, L. PRETE and B. SMULDERS, "The coming of age of infringement proceedings », Common Market Law Review Vol. 47, 2010, pp 9-61.

126 In Spirlea, the applicants had lodged a complaint of infringement against Germany for breach of a regulation on advanced therapy medicinal products (their child had died as a result of a treatment that would have been forbidden). The Court of Justice extended the scope of the presumption to EU Pilot procedures (Case C-562/14 P, Sweden v Commission (Spirlea), EU:C:2017:356, para 38, 39, 41, 44 and 45), against the advice of the AG SHARPSTON (Opinion, cit., para 43 to 54 ) and upheld $L P N$ also with regard to the conditions to prove an overriding public interest (para 55 to 57). In ClientEarth, the Court simply followed $L P N$ in this regard, holding that citizens' right to be "informed of the extent to which national law is compatible with European Union environmental law and to participate in the decision-making process" is too general a consideration to support reversing the application of the presumption (para 91 to 93). In Association Justice \& Environment, the applicants tried to reverse the strictness of the case law regarding the "overriding public interest" calling for a teleological interpretation that could favour access to documents in cases pertaining to environmental information, to no avail (Case T-727/15, Association Justice \& Environment v Commission, para 67 to 80). In Sumner, the Court precluded access to documents from being a vehicle of private enforcement of EU law in national courts on a matter where public interest considerations could also be at stake, given that the infringement procedure had been started by two trade unions (Loreto Sumner v Commission, Case T-152/17, EU:T:2018:875, para 62).

${ }^{127}$ LPN and Finland $v$ Commission, para 95. 
requested - shows that the Court admits an automatic application of the general presumptions, without consideration of the specific circumstances of the case to which it applies and without consideration for the democratic rationale of Regulation 1049/2001. ${ }^{128}$ The message is clear: when it comes to infringement procedures, it is the Commission alone who gets to define which information to be made public, by ensuring that "the public is informed about the progress of specific infringement cases through the regular publication of press releases". ${ }^{129}$

\subsection{Investigations}

Many of the cases where general presumptions have been recognised, including Commission infringement proceedings, have involved the protection of the purpose of investigations, under Article 4(2), $3^{\text {rd }}$ indent of Regulation 1049/2001. For this reason, the delimitation of the concept of investigations has the potential to restrict or broaden significantly the scope of access to documents. ${ }^{130}$ This issue arose in a case involving documents exchanged between a Member State and the Commission in the context of a procedure for the provision of information in the field of technical standards and regulations (Schlyter). ${ }^{131}$ According to EU law, national initiatives for the establishment of technical standards or regulations must be transparent. ${ }^{132}$ Member States need to communicate to the Commission draft technical regulations and their grounds, which must, in addition, be circulated among Member States. The purpose of this procedure is to enable the Commission and the other Member States to assess the possible internal market obstacles deriving from such initiatives and to enable the relevant Member State to accommodate the comments received in a final version of their own regulations. In this way, it is possible to avoid the adoption of national technical regulations that constitute an internal market obstacle. ${ }^{133}$ At first sight, these are regulatory procedures that ought, as a matter of principle, be in the public domain. While involving an assessment of compliance with EU law, little would indicate the need for confidentiality. This was, however, a contentious issue in Schlyter, pertaining to access to a

\footnotetext{
${ }^{128}$ Very much in the same line of LPN, see Association Justice \& Environment v Commission, para 52 to 61.

129 Association Justice \& Environment v Commission, para 60.

130 While this observation applies irrespective of the recognition of general presumptions, the impact of the latter in the possibility of having access to documents is such that makes the definition of the concept underlying the exception, arguably, more relevant.

131 Judgment of 7 September 2017, France v Carl Schlyter, Case C-331/15 P, EU:C:2017:639.

132 Currently, Directive 2015/1535 of the European Parliament and of the Council of 9 September 2015 laying down a procedure for the provision of information in the field of technical regulations and of rules on Information Society services (replaced the directives in force at the time of the facts).

${ }^{133}$ Judgment of 16 April 2015, Case T-402/12, Carl Schlyter v Commission, EU:T:2015:209, para 85.
} 
Commission's detailed opinion on a draft regulation submitted by France, while the procedure remained open.

The divergent positions expressed in this case regarding the purpose of this procedure and, particularly, what could undermine it, are paradigmatic of how differently the individual Member States and the Commission view the place of transparency in this context. France and the Commission sought to establish an analogy with infringement procedures, holding that, after the Commission issued a detailed opinion in the context of the said procedure, the "quality of the dialogue" between the Commission and the Member State needed to be protected. ${ }^{134}$ The Commission added that "those negotiations must be protected from any external pressure, for the Commission is trying to convince the Member State concerned that its draft national legislation could be incompatible with EU law and, often, suggests alternative solutions". ${ }^{135}$ Disclosure, in this case, undermines the "spirit of mutual trust" and the "willingness [of the Member State concerned] to cooperate", public information having thus a disruptive effect. ${ }^{136}$ Finland and Sweden disagreed that the procedure could even be considered an investigation for the purposes of Article 4(2), third paragraph. ${ }^{137}$ It is noteworthy that, as mentioned, at stake were drafts of national general norms on technical standards, their rationale, the possible obstacles to the internal market that they may pose, and the possible ways to make them conform to EU law.

Judging on appeal, the Court of Justice took a relatively broad definition of investigations, capable of encompassing the procedure at hand, disagreeing in this respect with the General Court. According to the Court of Justice, investigations are "structured and formalised Commission procedure [s] that ha[ve] the purpose of collecting and analysing information in order to enable the institution to take a position in the context of its functions provided for by the EU and FEU Treaties." ${ }^{138}$ Investigations, in the view of the Court, need not have the purpose of detecting an offence or illegality and can even conclude with a recommendation and not with a binding decision. ${ }^{139}$ Yet, diverging fundamentally from the arguments that France and the Commission had

\footnotetext{
134 France v Carl Schlyter, para 58 and 59.

135 France v Carl Schlyter, para 59.

136 France $v$ Carl Schlyter, para 62 and 64, referring to the positions of the Commission and of France, respectively.

137 Schlyter $v$ Commission, para 43.

${ }^{138}$ France $v$ Carl Schlyter, para 45 and 46. The Court thereby countered the definition that the General Court had adopted ("all the research carried out by a competent authority in order to establish that an infringement has taken place as well as the procedure by which an administrative body gathers information and checks certain facts before making a decision", Schlyter v Commission, para 53). For an application of this concept in another procedure, see Case T-128/14, Daimler v Commission, para 130 to 136, where the General Court refused the Commission's application of a general presumption of non-disclosure (para 152 to 164).

139 France $v$ Carl Schlyter, para 47 and 48.
} 
invoked, the Court did not consider that the purpose of the procedure required confidentiality. It rightly recalled that the procedure at stake, as envisaged in the applicable directive, was premised on transparency, including on the possibility of economic operators to issue opinions on the measures notified by a Member State. ${ }^{140}$ While it is not excluded that, in some cases, disclosure may indeed harm the purpose of the procedure (and hence may be refused on the basis of Article 4(2), third paragraph), the risk of disrupting the cooperation between the Commission and the Member State concerned is not a sufficient reason to deny access. It falls upon the Commission to demonstrate the specific and actual risk of undermining the objective of the procedure, i.e. preventing the adoption of a technical regulation incompatible with EU law. ${ }^{141}$

\subsection{Well-motivated international secrecies?}

Treaties, agreements and positions taken by the EU in the international plane, covering a wide range of issues that can significantly impact on citizens' rights and on the internal market (such as data, health and environmental protection) have gained increased public visibility in the last decade. Access to documents has been, as a result, at the core of heated debates on the limits of publicity of public action that has long stopped having effects limited to the diplomatic realm. The Courts' position with regard to access to information pertaining to the content of international negotiations has been consistent since, at least, the in't Veld cases. ${ }^{142}$ Thus, in view of the scope of the regulation on access to documents, transparency is a relevant consideration in international affairs, not least in a situation where the international agreements being negotiated may impact on the EU's legislative activity. ${ }^{143}$ Yet, both the General Court and the Court of Justice equally acknowledge the difficulties that may ensue from disclosing the content of the positions to be adopted by the EU in international negotiations and the limits posed to public involvement by the need to avoid revealing strategic elements of the negotiations. ${ }^{144}$ Accordingly, both Courts have hitherto consistently stressed "the singularly sensitive and essential nature of the protected

\footnotetext{
140 France v Carl Schlyter, para 72 to 80.

141 France $v$ Carl Schlyter, para 81 and 82.

142 The following will focus on this strand of case law in external relations. Another relevant aspect of access to documents in this field has been dealt in the context of restrictive measures adopted vis-à-vis individuals. See, in particular, Judgment of 1 February 2007, Sison v Council, C-266/05 P, EU:C:2007:75. In this respect, see, inter alia, H. FLAVIER, "Réflexions sur la Démocratisation des Relations Extérieures à l'Aune du Contentieux de l'Accès aux Documents » in E. NeFrAmi and M. GATTI (eds), Constitutional Issue of EU External Relations Law (Nomos), 2018, pp. 257-285, at pp. 275-285.

143 Sophie In't Veld v Council, Case T-529/09, EU:T:2012:215, para 89

${ }^{144}$ In't Veld v Council, para 88; Case T-301/10, Sophie In't Veld v Commission (ACTA), para 120. This reflects the widely accepted position that secrecy may be warranted in external relations, more intensely than in other policy fields, as the best way to preserve the public interest (in this sense, H. FLAVIER, op. cit., at p.275).
} 
interest" covered by the international relations exception, be it in cases where at stake was the disclosure of EU positions during international negotiations or not. ${ }^{145}$ Technically, the scheme of the exceptions in Article 4(1)(a) added further strength to the position of the Courts according to which the institutions enjoy wide discretion in assessing the possibility of harm to the protection of international relations. In fact, the exception is "framed in mandatory terms" (i.e. if the institution establishes a harm to the protection of international negotiations, it is "obliged to refuse access" and it is not required to balance such harm with an overriding public interest) and provides only "very general" criteria. ${ }^{146}$ The implication is well-known: in the face of broad discretionary decisions, the Court performs, in principle, a limited review of their legality.

Based on these premises, the General Court has upheld refusals of access, inter alia, to: documents containing legal advice on a Commission recommendation to open negotiations with the US on data processing and exchange for purposes of police cooperation, which could reveal the objectives pursued by the $\mathrm{EU}$ in the negotiations; ${ }^{147}$ international negotiating documents relating to the draft Anti-Counterfeiting Trade Agreement; ${ }^{148}$ negotiation directives given by the Council to the Commission in its capacity as negotiator of the EU's accession agreement to the European Convention on Human Rights; ${ }^{149}$ emails containing comments by the Commission's Legal Service on the treatment to be given to Syrian nationals in the framework of the EU-Turkey Agreement on the return and resettlement of migrants and irregular migration; ${ }^{150}$ documents pertaining to the legality of the Investment State Dispute Settlement and Investment Court System, as capable of disclosing the Union's position on ongoing negotiations. ${ }^{151}$ On the other hand, it has recognised access to, inter alia: part of documents the disclosure of which is unlikely to damage the mutual trust between the negotiating parties; ${ }^{152}$ negotiating directives that had already been communicated to negotiating partners (the Council could no longer argue that disclosure would

\footnotetext{
145 Judgments of 1 February 2007, Sison v Council, C-266/05 P, EU:C:2007:75, paragraph 35; In't Veld v Council, para 24; In't Veld v Commission (ACTA), para 108; Besselink v Council, Case T-331/11, EU:T:2013:419, para 32; Case T852/16, Access Info Europe (EU Turkey Agreement), para 38; Case T-644/16, ClientEarth v Commission (ISDS and ICS), para 23 (under appeal at the time of the writing).

146 In't Veld v Commission (ACT A), para 108 (referring however, to "ome discretion"); Besselink, para 32 to 34, 44 and 51. Case T-852/16, Access Info Europe v Commission (EU Turkey Agreement), para 38 to 40; Case T-644/16, ClientEarth v Commission (ISDS and ICS), para 23 to 25 (under appeal). See also In't Veld v Council, para 23 to 25 (and Case C-350/12 $\mathrm{P}$, Council v Sophie In't Veld, para 63).

147 In't Veld v Council, para 35 to 39.

148 In't Veld v Commission (ACTA), para 106 to 197.

149 Besselink v Council, para 70 to 73.

150 Access Info Europe (EU Turkey Agreement), para 43 to 46, and 84 to 88.

151 ClientEarth v Commission (ISDS and ICS), para 37 to 48.

152 In't Veld v Commission (ACTA), para 183 to 185.
} 
effectively weaken the Union's negotiation position); ${ }^{153}$ documents containing a legal assessment of the legislation of a Member State, not involving a position taken vis-à-vis a third State. ${ }^{154}$

Overall, the openness that the case law has allowed for is rather limited. ${ }^{155}$ The Court is, in principle, opposed to disclosing negotiation directives that are not in the public domain, in order to preserve a climate of trust between negotiating partners and the international capacity of the EU. ${ }^{156}$ This includes precluding access to information on constitutional matters, such as the legal basis of the conclusion of the envisaged international agreement, if it can disclose the content of the Union's position and cause sufficient harm to the protection of international relations, or, for the same reason, the way in which the Union envisaged its accession to the European Convention of Human Rights (a matter which the Court did not consider to be of constitutional nature). ${ }^{157}$ The judgments are of course always based on an assessment of the position of the parties pleading in opposite directions, and the Court makes clear that the institutions wishing to preclude disclosure need to demonstrate before the court the existence of a specific and effective risk to the protection of international relations, not purely based on hypothetical scenarios, providing, to this extent, a sufficient protection of transparency. ${ }^{158}$ No general presumptions of non-disclosure apply in this case. Yet, "plausible explanations" based on general considerations (such as the possibility that documents include tactical considerations, the possibility that knowledge of negotiating directives might have been exploited by negotiating partners) can be sufficient to establish the required level of risk. ${ }^{159}$ In addition, summary statements are sufficient, at the risk of otherwise effectively disclosing information on the content of the documents that the institutions wish to withhold from the public domain, in view of Article 4(1)(a). ${ }^{160}$

\section{Pervasive, but not so much}

\footnotetext{
153 Besselink v Council, para 58 to 60.

154 Access Info Europe (EU Turkey Agreement), para 48 and 49

155 See, in more detail, P. LEINO, «The Principle of Transparency in EU External Relations Law » in M. CREMONA (ed.) Structural Principles in EU External Relations Law, OUP, 2018, pp. 201-223.

156 H. Flavier, op. cit., p. 266-7, 270-1.

157 Case C-350/12 P, Council v Sophie In't Veld, para 43,44, 54 (in this case, a contrario); Besselink v Council, para 43 and 45.

158 Besselink v Council, para 50.

159 "Plausible explanations" are mentioned in Access Info Europe (EU Turkey Agreement), para 41. On the grounds mentioned in the text, see In't Veld v Commission (ACTA), para 125, Besselink v Council, para 71, Access Info Europe (EU Turkey Agreement), para 45.

160 Access Info Europe (EU Turkey Agreement), para 51.
} 
Those who would hope to see in the advancement of transparency one of the signs of the democratic character of the EU can be either disappointed or rebutted in view of how the right of access to documents has evolved in EU law. Its nature as a citizens' fundamental right (Article 42 of the Charter) to be exercised in a polity progressively evolving towards an ideal of openness (Article 15(1) TFEU) has done little to break the spheres of confidentiality dictated by the "nature" of the EU procedures, despite significant exceptions where institutional practice was strongly in contrast with core tenets of representative democracy (such as, for example, the open nature of legislative deliberations, as in the case of trialogues).

The above overview shows that, despite the progress towards increased transparency, a right ancillary to democratic claims can face significant barriers to change the nature of the polity and of the system of governance in which it is embedded. If in the field of external relations, the demands for secrecy can find justification in reasons equally accepted in the laws of the Member States, other settings involving state sovereignty within the EU reveal clearly how far both the Member States and the EU institutions (including the Court) are willing to go in transforming the EU into a polity where citizens are informed of the contours of public action. Not far, when it comes to Commission infringement procedures.

Despite the encompassing wording of Regulation 1049/2001, it appears that access to documents - at least as interpreted by the Court - was never meant to transform the legal and constitutional set up of certain procedures, the closed character of infringement procedures being a case in point. In this respect, the Court's interpretation of the regime on access to documents is preserving the effectiveness of EU law, by protecting the prerogatives of the Commission, conditioning the rationale of Regulation 1049/2001 accordingly. As before the entry into force of the Lisbon Treaty, transparency is a principle that remains contingent on the needs of European integration (in addition to the protection of the interests specified in Regulation 1049/200) as the EU institutions define them. In the case of administrative procedures to which specific legal regimes apply, the application of general presumptions of non-disclosure shows that it is the task of the legislature to delineate the balance between openness and confidentiality, again carving out specific regimes of access to documents pertaining to an administrative file. That these prevail as lex specialis (as a result of the application of general presumptions) shows also, albeit in a different way, the boundaries of a transparency regime informed by the principle of democracy. Either sector rules take transparency as a relevant consideration in shaping specific regimes of access to files, or arguments based on the general regime on access to documents can hardly correct possible excesses in the direction of confidentiality, given the current obstacles to invert general presumptions where they are systematically applied. 
The analysis in this chapter has also shown that the ambivalence of transparency, in particular in the context of EU integration, is an important consideration when making normative assessments of how far the EU is compliant with that constitutional principle. The functional roots of transparency in the EU remain present and cannot be ignored by those who advocate transparency as a democratic principle. In particular at a time in which the terms of the debate on transparency are changing under the pressure of ever more available information, of the concerns for privacy, and of the very way procedures are conducted via new technologies, a reflection on the meaning of transparency, its limits, usages and political effects in the EU is essential to define both possible needed reforms but also which public measures may be needed to realise the abstract ideals that it stands for. 